\title{
A COMPARATIVE STUDY OF DATA COLLECTION METHODS IN THE PROCESS OF NURSING: DETECTION OF CHEMOTHERAPY SIDE EFFECTS USING A SELF-REPORTING QUESTIONNAIRE
}

\author{
Marco Di Muzio ${ }^{1}$, Alessandra Marinucci² ${ }^{2}$ Anna De Benedictis ${ }^{2}$ and Daniela Tartaglini ${ }^{2}$ \\ ${ }^{1}$ Department of Public Health and Infectious Diseases, Sapienza University of Rome, Rome, Italy; \\ ${ }^{2}$ University Campus Bio-Medico, Rome, Italy
}

\begin{abstract}
SUMMARY - Toxicity of chemotherapy is a factor that most negatively affects the quality of life of cancer patients. Monitoring of side effects and adverse effects may be subject to errors due to various factors such as the lack of privacy during data collection, shame on the part of the patient to talk about some issues, lack of recognition of symptoms and/or unawareness of side effects of treatments, and/or inappropriate reference model of data collection. In order to assist caregivers in proper data collection, a 'self-reporting questionnaire' was designed. The questionnaire was developed using validated scales such as the Common Terminology Criteria for Adverse Event, Edmonton Symptom Assessment Scale and Douleur Neuropathique en 4 Questions. The survey involved the population of patients scheduled for chemotherapy in Day Hospital at the Campus Bio-Medico University Hospital, Rome, between June and July 2015. During the period of observation, 367 patients were admitted to Day Hospital, $57.5 \%$ of women and $38.4 \%$ of men, average age 64 years, for a total of 622 accesses; of these, only 173 were interviewed by the nursing staff in relation to side effects and toxicity. During the trial, 381 patients were involved, of which $60.1 \%$ of women $(p=0.8)$ and $38.3 \%$ of men $(p=0.9)$, average age 63 years $(\mathrm{p}=0.9)$, for a total of 611 accesses and 498 self-reporting questionnaires administered. At the end of the trial period, in order to evaluate usability, an evaluation questionnaire was given to medical personnel, including five doctors and six nurses, to consider possible amendments to the instrument and its perceived effectiveness. Comparative analysis of data collected during the observation period and the trial showed how the use of the self-reporting questionnaire allowed for detection of side effects of chemotherapy earlier and in a more detailed way than relying only on medical examination and unstructured interview by nursing staff. It also enabled reaching a larger number of users. In conclusion, the use of self-reporting systems, together with the work and clinical judgment of the expert, can contribute to improvement in the patient quality of life, corroborating nurse interviews through a precise and systematic data collection process that reduces the amount of interpretation of symptoms by the patient and the caregiver, while providing them with precise instructions on what to report and how to report it. The significant and rapid spread of computers, tablets and smartphones allows for speculating on further use and implementation of this system through its computerized application.
\end{abstract}

Key words: Nursing process; Data collection; Neoplasms - drug therapy; Antineoplastic drugs - adverse effects; Surveys and questionnaires; Self-assessment

\section{Introduction}

Toxicity of chemotherapy is a factor that most negatively affects the quality of life of cancer patients. $\mathrm{Cy}$ totoxic effects ${ }^{1-3}$ become evident as undesirable clinical
Correspondence to: Alessandra Marinucci, $M D$, University Campus Bio-Medico, Via Alvaro del Portillo 200, 00128, Rome, Italy. E-mail: a.marinucci@unicampus.it

Received February 8,2016, accepted June 9, 2017 
symptoms that occur after administration of most anti-cancer therapies, due to the low therapeutic index of chemotherapy drugs ${ }^{4-6}$. The problem associated with this therapy is poor cellular selectivity; moreover, toxic effects often overlap with therapeutic effects as healthy cells are also damaged by the treatment. These symptoms usually disappear once the treatment ends, but their underestimation, lack of timely treatment, or perpetration of exposure to chemotherapeutic agents may lead to irreversible damage to the patient or to the need to suspend a therapeutically effective treatment, thus causing death.

In managing side effects, it is essential to know the probability of toxic response ${ }^{1,3,7}$ to chemotherapy and to properly assess the signs and symptoms in the patient before and during treatment, to avoid errors in therapeutic decisions. Cancer patients may indeed show one or more symptoms related to the disease and/or to therapies that influence their daily life, independently of the stage and spread of the disease; often in addition, some symptoms are not immediately recognized or are underestimated by the oncologist ${ }^{8}$.

Monitoring of side effects and adverse events may, however, also be subject to errors and/or omissions due to various factors including the lack of privacy during data collection, shame on the side of the patient to talk about some issues, the lack of recognition of symptomatology and/or unawareness of the treatment side effects, or inappropriate reference model of data collection $^{9,10}$.

To this purpose, validated scales ${ }^{11}$ have been established to provide support in detection and treatment of symptoms, with the aim to improve the quality of life of patients and their families and guarantee continuous care through early integration of simultaneous care first and palliative care afterwards.

In the literature, there are no articles on validation of a 'self-reporting questionnaire' in terms of detection of toxicity and side effects associated with chemotherapy. However, field studies use this technique for collecting monitoring data in home care and outpatient environments through the application of the Common Terminology Criteria for Adverse Event (CTCAE $)^{12,13}$. Studies suggest CTCAE as a valid source of information in addition to clinical data for detection of chemotherapy toxicity ${ }^{14,15}$.

In this regard, this project aimed to create a selfreporting questionnaire in order to improve data col- lection related to chemotherapy side effects, improve reception of the patient, and minimize prescription errors due to:

- absence of dedicated reception areas;

- lack of privacy;

- uneasiness;

- non-recognition of symptoms;

- patient inability to describe or quantify symptoms;

- unawareness of side effects of treatments; and

- inadequate reference model of data collection.

\section{Subjects and Methods}

In order to assess usefulness and effectiveness of the self-reporting questionnaire administered to cancer patients, a one-month period of observation was carried out on the data collection method utilized by the medical and nursing staff at the Oncology Day Hospital, Campus Bio-Medico di Roma. It was followed by a comparable period of experimentation of the self-reporting questionnaire.

The self-reporting questionnaire (available on request) has been developed using validated scales such as the CTCAE ${ }^{12,13}$, the Edmonton Symptom Assessment Scale $(\mathrm{ESAS})^{16,17}$, and Douleur Neuropathique en 4 Questions (DN4) ${ }^{18,19}$.

In developing the questionnaire, symptoms were considered that are more easily recognizable and quantifiable by the patient, and the manifestation of which precludes administration of chemotherapy.

At the end of the trial period, an evaluation questionnaire was given to physicians and nurses in the Oncology Day Hospital to assess the usability of the self-reporting questionnaire.

The evaluation questionnaire on practicality and usability of the self-reporting questionnaire by health workers has been designed on the basis of previous internal reports performed at the Hospital Campus BioMedico of Rome by the Group of Improvement JCI (Joint Commission International) Clinical Risk Management, as well as the usability requirements expressed in the Development of a Model of Integrated Patient Folder project of the Ministry of Health ${ }^{20}$.

Eight questions were identified with 5 possible answers on a Likert scale, from excellent to inadequate, in addition to the years of service in the oncology area, particularly at the Day Hospital, and 3 open questions. 


\section{Sample}

The self-reporting questionnaire was administered to all patients scheduled for chemotherapy in Day Hospital at the Campus Bio-Medico of Rome, with approval from the Hospital Health Management. A total of 498 questionnaires were administered.

During the period of observation, 367 patients were admitted to Day Hospital, $57.5 \%$ of women and $38.4 \%$ of men, average age 64 years. For $4.1 \%$ of them, it was not possible to determine their sexual category because of incomplete master data. Total number of accesses was 622; of these, 173 were interviewed by the nursing staff concerning side effects and toxicity.

During the trial, 381 patients were involved, 60.1\% of women $(\mathrm{p}=0.8)$ and $38.3 \%$ of men $(\mathrm{p}=0.9)$, average age 63 years $(\mathrm{p}=0.9)$, while for $1.6 \%$ it was not possible to determine sexual category. Total number of admissions was 611 .

The following therapies were administered during the two study periods: alkylating agents $2.2 \%$ vs. $3.5 \%$,

\section{Table 1. Toxicity revelation}

\begin{tabular}{|l|l|l|}
\hline & $\begin{array}{l}\text { Observational } \\
\text { group: interview }\end{array}$ & $\begin{array}{l}\text { Experimental group: } \\
\text { self-reporting } \\
\text { questionnaire }\end{array}$ \\
\hline $\begin{array}{l}\text { Total } \\
\text { admission } \\
\text { Interview/ } \\
\text { questionnaire }\end{array}$ & 622 & 611 \\
$\begin{array}{l}\text { Reported } \\
\text { toxicity } \\
\text { Mean toxicity } \\
\text { by patient }\end{array}$ & 613 & 498 \\
\hline
\end{tabular}

$\mathrm{p}=0.8,13 \%$ vs. $10.4 \%$ antimetabolites $\mathrm{p}=0.7$, antimitotic $9.4 \%$ vs. $10.7 \%, \mathrm{p}=0.94$, cytotoxic antibiotics $0.5 \%$ vs. $0 \% \mathrm{p}=0.47$, targeted therapies $30.4 \%$ vs. $33.3 \%$ $\mathrm{p}=0.77$, hormones and hormone antagonists $6.9 \%$ vs. $5.6 \% \mathrm{p}=0.93$, various agents $4.7 \%$ vs. $4.2 \% \mathrm{p}=0.86$, and polychemotherapies $32.9 \%$ vs. $32.3 \% \mathrm{p}=0.95$.

The two samples did not show statistically significant differences and were found to be consistent with the existing clinical and epidemiological national studies $^{4}$.

The medical staff of the Department of Oncology Day Hospital, Campus Bio-Medico University Hospital, Rome, which filled-out the evaluation questionnaire consisted of 5 medical specialists, including 2 specialists and 3 interns; as for the nursing staff, the questionnaire was administered to 6 nurses working in the oncology area in June, totaling 11 questionnaires to assess the usability of the tool.

The two populations were compared by standard statistical measurements of the mean, standard deviation and percentage. The values of $\mathrm{p}$ were calculated by the $\chi^{2}$-test for discontinuous variables and Student's T test for continuous variables. The values of $p<0.05$ were considered statistically significant.

The study was approved by the Ethics Committee of the Campus Bio-Medico University Hospital, Rome, Italy.

\section{Results}

The research results proved to be consistent with those reported from scientific studies in the field. Comparative analysis of data collected during the observation period and the trial revealed that the use of

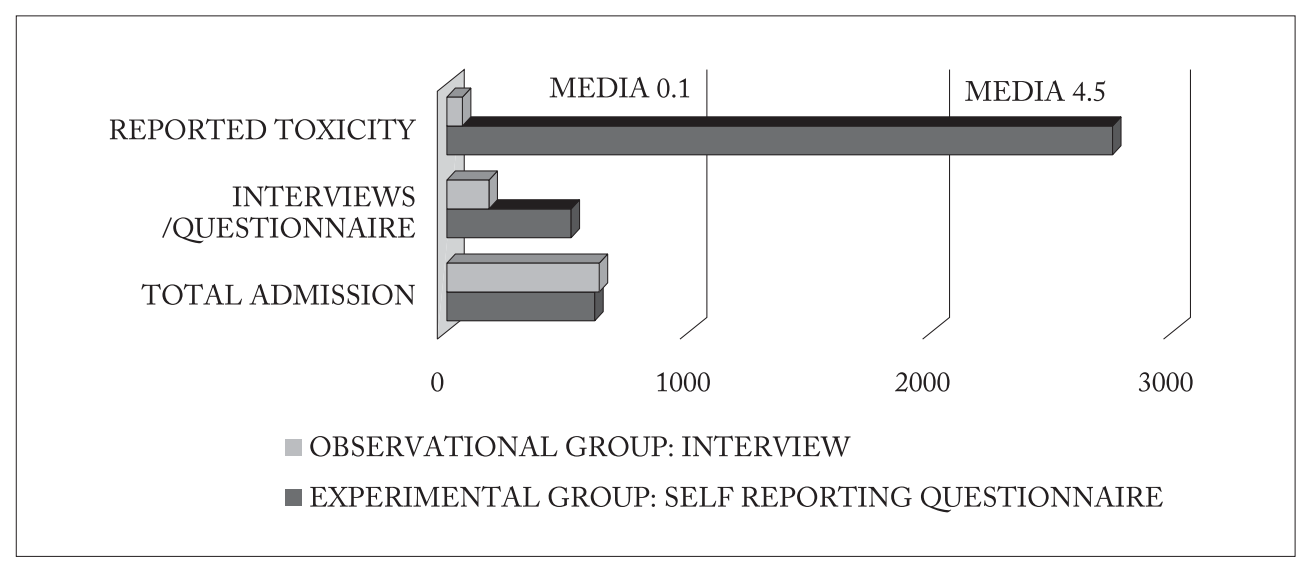

Fig. 1. Toxicity revelation. 
Table 2. Chemotherapy toxicity and side effects

\begin{tabular}{|l|l|l|l|l|}
\hline & Toxicity and side effects & Observational group (\%) & Experimental group (\%) & p \\
\hline Common & Hyperthermia & 2.3 & 3.6 & 0.9 \\
Terminology & Skin reaction & 2.3 & 18.7 & 0.0004 \\
Criteria for Adverse & Mucositis & 0 & 16.5 & 0.0001 \\
Event (CTCAE) & Gastric toxicity & 7.2 & 6 & 0.14 \\
& Bowel toxicity & 7 & 33.7 & 0.0000 \\
\hline Edmonton & Pain & 5.8 & 41.4 & 0.0000 \\
Symptom & Tiredness & 2.3 & 74.1 & 0.0000 \\
Assessment Scale & Nausea & 0 & 28.9 & 0.0000 \\
(ESAS) & Depression & 0 & 31.7 & 0.0000 \\
& Anxiety & 0 & 41.6 & 0.0000 \\
& Drowsiness & 0 & 51.4 & 0.0000 \\
& Lack of appetite & 0.6 & 33.1 & 0.0000 \\
& Wellbeing & 0 & 40.2 & 0.0000 \\
Douleur & Shortness of breath & Burn & 24.9 & 0.0000 \\
neuropathique & Cold & 0 & 9.8 & 0.0039 \\
en 4 questions & Electric shock & 0.6 & 6.2 & 0.0339 \\
(DN4) & Numbness & 2.9 & 11.4 & 0.0035 \\
& Painful cold & 0 & 25.9 & 0.0000 \\
& Electric shock & Itching & 5.6 & 0.0486 \\
& Pain evoked by light touching & 0 & 10 & 0.0035 \\
& Others & 5.8 & 0.6 & 0.0031 \\
& & 0.6 & 0.0181 \\
& & 0.0010 \\
\hline
\end{tabular}

the self-reporting questionnaire allowed for detection of chemotherapy side effects earlier and in a more detailed way than relying only on medical examination and unstructured interviewing by nursing staff. It also enabled reaching a larger number of users (Table 1, Fig. 1).

Careful analysis of the types of toxicity observed in the nursing interviews and questionnaires showed how the adverse event monitoring by clinicians during chemotherapy often did not take into account the subjective and emotional components, as well as the implication these symptoms may have in daily life; comparison of the symptoms self-reported by patients with those recorded by nurses revealed that patients and nurses agreed on the incidence of the most common and/or objectifiable symptoms such as hyperthermia and gastric toxicity, but they did not agree on less widespread toxicities that go unrecognized by the population as potential effects of chemotherapy, as well as on psychosomatic states. These conditions often are not considered really compromising by attending physicians from a prescriptive point of view, but prove to be highly invalidating ${ }^{21-23}$ from the point of view of patients. In particular, highly significant results are achieved concerning the presence of alteration of bowel function, pain, anxiety and depression, malaise, fatigue and abnormal sleep-rest pattern ${ }^{8,24}$, as such toxicities, very frequently suggested by patients, tend to be underestimated and undervalued by operators ${ }^{25-29}$ (Table 2, Fig. 2).

\section{Discussion and Conclusions}

The use of self-reporting systems, together with the work and clinical judgment of the expert, can contribute to improvement in the quality of life of cancer patients. It also helps the nurse in conducting patient interview through precise and systematic data collec- 


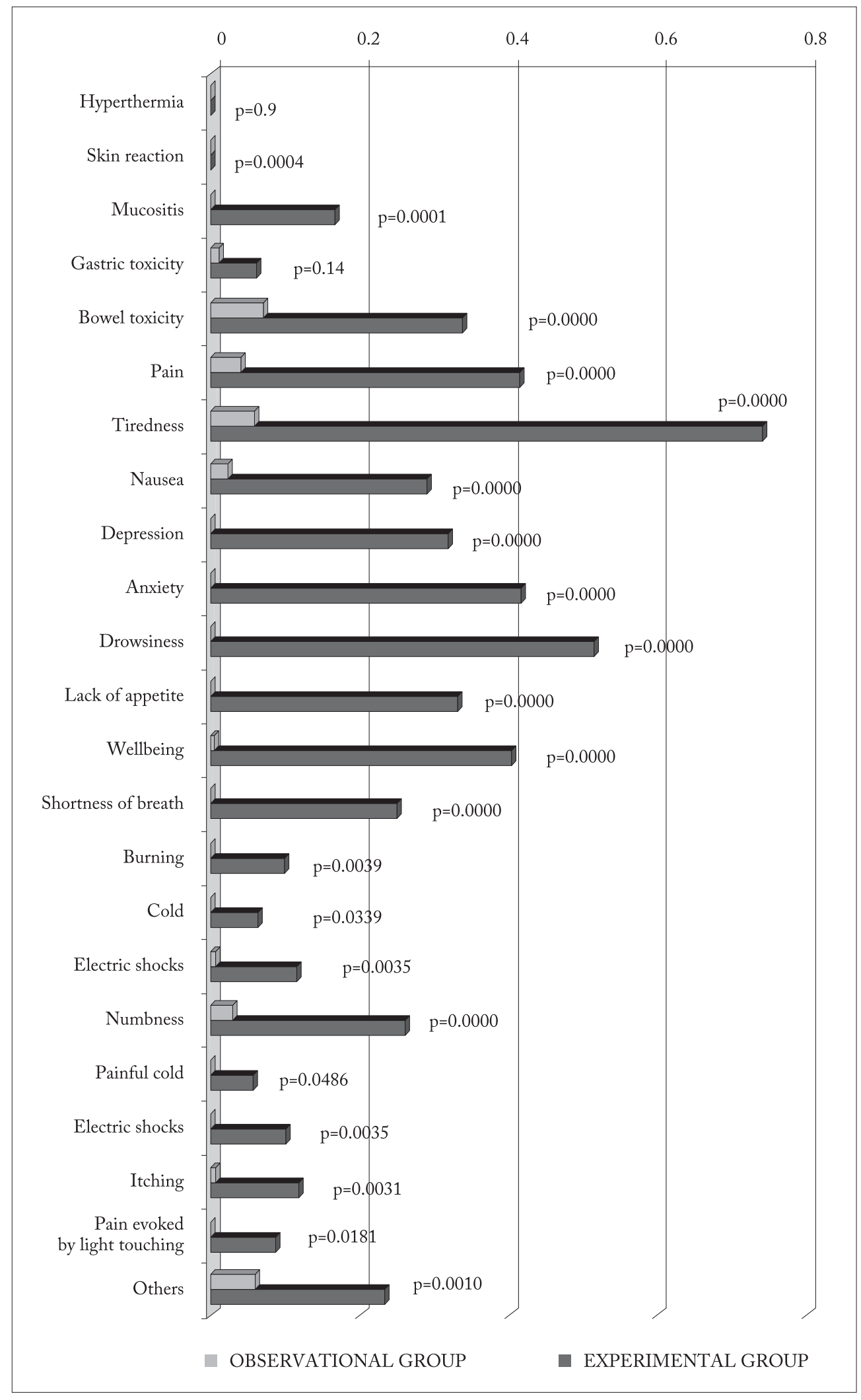

Fig. 2. Chemotherapy toxicity and side effects. 
Table 3. Folders filling correctly

\begin{tabular}{|l|l|l|l|}
\hline & $\begin{array}{l}\text { Observational } \\
\text { group }\end{array}$ & $\begin{array}{l}\text { Experimental } \\
\text { group }\end{array}$ & $\mathrm{p}$ \\
\hline $\begin{array}{l}\text { Folders filling } \\
\text { correctly }\end{array}$ & $27.8 \%$ & $82 \%$ & 0.0000 \\
\hline
\end{tabular}

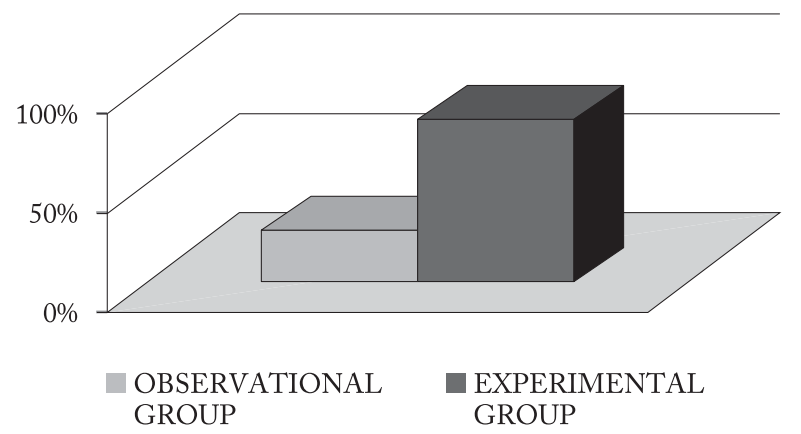

Fig. 3. Folders filling correctly.

tion. This in turn reduces the interpretative amount of symptoms by patients and caregivers, while providing them with precise instructions on what to report and how to report it.

The method of self-administration also guarantees more privacy and freedom to reveal symptoms that are deemed embarrassing. The use of a standardized form allows for reporting real and relevant data into computerized medical records, thus guaranteeing storage of information towards greater continuity of care.

The tool also shows good versatility of use; its use as a checklist during the active interview by physicians and nurses can be anticipated, in addition to the selfadministration mode, whereas privacy conditions are guaranteed.

The significant and rapid availability of computers, tablets and smartphones, which in recent years has involved not only young people but also people of all ages and social classes, also allows to envision further use and implementation of this system through its computerized application, as already happens internationally ${ }^{30}$. Specifically, one might think to fill-in an online questionnaire in order to allow regular monitoring of patient symptoms, their performance status and their needs, as well as to obtain information on the patient health in real-time, thus improving efficiency and quality of care, communication and help requests ${ }^{31}$.

The use of telemedicine systems in oncology is expected to be on an equal footing with those already widespread in Italy for the care of patients with chronic degenerative diseases. The use of such technologies would improve clinical care ${ }^{32}$ by reporting symptoms with consistent time savings through standardized methods and addressing useful links for clinical treatment, such as summary reports in the patient computerized medical record and immediate e-mail alerts to healthcare personnel whenever patients report acute needs $s^{33}$.

Ultimately, the importance of maintaining an effective physician/nurse-patient relationship cannot be underemphasized in order to avoid depersonalization of the helping relationship that the exclusive use of computerized methods may entail.

\section{Acknowledgment}

This work was supported by the Campus BioMedico University Hospital, Rome, Italy.

\section{References}

1. Bonadonna G, Robustelli della Cuna G, Valagussa P. Medicina oncologica. Milan: Elsevier, 2009. (in Italian)

2. Skeel RT. Handbook of Cancer Chemotherapy. Philadelphia, USA: Lippincott, Williams \& Wilkins, 2007.

3. Palozzo AC. Vademecum di terapia oncologica. Milan: Infosan, 2010. (in Italian)

4. Pontieri GM. Elementi di patologia generale. Padua: Piccin, 2003. (in Italian)

5. Cotran RS, Kumar V, Robbins SL. Le basi patologiche delle malattie. Vol. 1. Padua: Piccin, 1997. (in Italian)

6. Marchini J, Cardon LR, Phillips MS, Donnelly P. The effects of human population structure on large genetic association studies. Nat Genet. 2004 May;36(5):512-7. doi: 10.1038/ng1337

7. Grossi F. CTAE in the pocket, traduzione italiana dei common terminology criteria for adverse events. Medicom Divisione di Springer Verlag Italia, Geca Spa, Cesano Boscone, Milan, 2011. (in Italian)

8. Basch E, Jia X, Heller G, Barz A, Sit L, Fruscione M, Appawu M, Iasonos A, Atkinson T, Goldfarb S, Culkin A, Kris MG, Schrag D. Adverse symptom event reporting by patients vs clinicians: relationships with clinical outcomes. J Natl Cancer Inst. 2009 Dec 2;101(23):1624-32. doi: 10.1093/jnci/djp386

9. Gordon M. Diagnosi infermieristiche. Processo e applicazioni. Milan: Casa Editrice Ambrosiana, 2009. (in Italian)

10. Brachelente C, Esposito G. Documentazione e classificazione dell'attività infermieristica, la necessità di classificare. G Med Mil. 2012;162 (1):95-8. (in Italian)

11. Valutazione e trattamento dei sintomi nel malato oncologico, per una precoce integrazione delle cure oncologiche e palliative 
(Cure Simultanee). Retrieved Sep 13, 2015, from http://www. aiom.it/C_Common/Download.asp?file=/\$Site $\$ /$ Attivita_Scientifica/2014_pocket_sintomi_AIOM.pdf (in Italian)

12. Gestione della tossicità ematopoietica in oncologia. Linee guida AIOM 2013. Retrieved Apr 14, 2015, from http://www. aiom.it/area+pubblica/area+medica/prodotti+scientifici/linee+ guida/Gestione+della+tossicita\%27+ematopoietica+in+oncolo gia/1\%2C $3131 \% 2 \mathrm{C} 1 \% 2 \mathrm{C}$ (in Italian)

13. Greil R, Thodtman R, Roila F. ESMO Guidelines Working Group. Erythropoietins in cancer patients: ESMO recommendations for use. Ann Oncol. 2008 May;19 Suppl 2. doi: 10.1093 /annonc/mdn106

14. Lester J, Bernhard L, Ryan-Wenger N. A self-report instrument that describes urogenital atrophy symptoms in breast cancer survivors. West J Nurs Res. 2012 Feb;34(1):72-96. doi: 10.1177/0193945910391483

15. Basch E, Iasonos A, Barz A, Culkin A, Kris MG, Artz D, Fearn P, Speakman J, Farquhar R, Scher HI, McCabe M, Schrag D. Long-term toxicity monitoring via electronic patient-reported outcomes in patients receiving chemotherapy. J Clin Oncol. 2007 Dec 1;25(34):5374-80. doi: 10.1200/JCO.2007.11.2243

16. Bruera E. The Edmonton Symptom Assessment System (ESAS): a simple method for the assessment of palliative care patients. J Palliat Care. 1991;7(2):6-9.

17. Moro C, Brunelli C, Miccinesi G. Edmonton Symptom Assessment Scale: Italian validation in two palliative care settings. Support Care Cancer. 2006 Jan;14(1):30-7. doi: 10.1007/s00520-005-0834-3

18. Bouhassira D, Attal N, Alchaar H, Boureau F, Brochet B, Bruxelle J, Cunin G, Fermanian J, Ginies P, Grun-Overdyking A, Jafari-Schluep H, Lantéri-Minet M, Laurent B, Mick G, Serrie A, Valade D, Vicaut E. Comparison of pain syndromes associated with nervous or somatic lesions and development of a new neuropathic pain diagnostic questionnaire (DN4). Pain. 2005;114:29-36. doi: 10.1016/j.pain.2004.12.010

19. Spallone V, Morganti R, D'Amato C, Greco C, Cacciotti L, Marfia GA. Validation of DN4 as a screening tool for neuropathic pain in painful diabetic polyneuropathy. Diabet Med. 2012;29:578-85. doi: 10.1111/j.1464-5491.2011.03500.x

20. Sviluppo di un Modello di Cartella Paziente Integrata. Retrieved Jul 27, 2015, from www.salute.gov.it/imgs/c_17_pubblicazioni1697_allegato.pdf (in Italian)

21. Anderson JG, Taylor AG. Use of complementary therapies for cancer symptom management: results of the 2007 National Health Interview Survey. J Altern Complement Med. 2012 Mar;18(3):235-41. doi: 10.1089/acm.2011.0022

22. Kim KS, Kwon SH. Comfort and quality of life of cancer patients. Asian Nurs Res (Korean Soc Nurs Sci). 2007 Sep;1 (2):125-35. doi: 10.1016/S1976-1317(08)60015-8

23. Belqaid K, Orrevall Y, McGreevy J, Månsson-Brahme E, Wismer W, Tishelman C, Bernhardson BM. Self-reported taste and smell alterations in patients under investigation for lung cancer. Acta Oncol. 2014 Oct;53(10):1405-12. doi: 10.3109/0284186X.2014.895035
24. Andikyan V, Rezk Y, Einstein MH, Gualtiere G, Leitao MM Jr, Sonoda Y, Abu-Rustum NR, Barakat RR, Basch EM, Chi DS. A prospective study of the feasibility and acceptability of a web-based, electronic patient-reported outcome system in assessing patient recovery after major gynecologic cancer surgery. Gynecol Oncol. 2012 Nov;127(2):273-7. doi: 10.1016/j.ygyno.2012.07.124

25. Cirillo M, Venturini M, Ciccarelli L, Coati F, Bortolami O, Verlato G. Clinician versus nurse symptom reporting using the National Cancer Institute-Common Terminology Criteria for Adverse Events during chemotherapy: results of a comparison based on patient's self-reported questionnaire. Ann Oncol. 2009 Dec;20(12):1929-35.

doi: $10.1093 /$ annonc/mdp287

26. Quinten C, Maringwa J, Gotay CC, Martinelli F, Coens C, Reeve BB, Flechtner H, Greimel E, King M, Osoba D, Cleeland C, Ringash J, Schmucker-Von Koch J, Taphoorn MJ, Weis J, Bottomley A. Patient self-reports of symptoms and clinician ratings as predictors of overall cancer survival. J Natl Cancer Inst. 2011 Dec 21;103(24):1851-8. doi: $10.1093 /$ jnci/djr485

27. Shun SC, Lai YH, Hsiao FH. Patient-related barriers to fatigue communication in cancer patients receiving active treatment. Oncologist. 2009 Sep;14(9):936-43.

doi: 10.1634/theoncologist.2009-0048

28. Siefert ML, Hong F, Valcarce B, Berry DL. Patient and clinician communication of self-reported insomnia during ambulatory cancer care clinic visits. Cancer Nurs. 2014 Mar-Apr; 37(2):E51-9. doi: 10.1097/NCC.0b013e318283a7bc

29. Linee guida sull'assistenza psicosociale dei malati oncologici. Linee guida AIOM 2013. Retrieved September 20, 2015, from http://www.aiom.it/area+pubblica/area+medica/prodotti+scientifici/linee+guida/assistenza+psicosociale+dei+malati+oncol ogici/1\%2C1999\%2C1\%2C (in Italian)

30. Min YH, Lee JW, Shin YW, Jo MW, Sohn G, Lee JH, Lee G, Jung KH, Sung J, Ko BS, Yu JH, Kim HJ, Son BH, Ahn SH. Daily collection of self-reporting sleep disturbance data via a smartphone app in breast cancer patients receiving chemotherapy: a feasibility study. J Med Internet Res. 2014 May 23;16(5):e135. doi: 10.2196/jmir.3421

31. Berry DL, Hong F, Halpenny B, Partridge A, Fox E, Fann JR, Wolpin S, Lober WB, Bush N, Parvathaneni U, Amtmann D, Ford R. The electronic self report assessment and intervention for cancer: promoting patient verbal reporting of symptom and quality of life issues in a randomized controlled trial. BMC Cancer. 2014 Jul 12;14:513. doi: 10.1186/1471-2407-14-513

32. Basch E, Artz D, Iasonos A, Speakman J, Shannon K, Lin K, Pun C, Yong H, Fearn P, Barz A, Scher HI, McCabe M, Schrag D. Evaluation of an online platform for cancer patient self-reporting of chemotherapy toxicities. J Am Med Inform Assoc. 2007 May-Jun;14(3):264-8. doi: 10.1197/jamia.M2177

33. Bennett AV, Jensen RE, Basch E. Electronic patient-reported outcome systems in oncology clinical practice. CA Cancer J Clin. 2012 Sep-Oct;62(5):337-47. doi: 10.3322/caac.21150 


\section{Sažetak USPOREDBENO ISTRAŽIVANJE METODA PRIKUPLJANJA PODATAKA
U PROCESU SESTRINSKE NJEGE: OTKRIVANJE NUSPOJAVA KEMOTERAPIJE
POMOĆU UPITNIKA ZA SAMOPROCJENU}

M. Di Muzio, A. Marinucci, A. De Benedictis i D. Tartaglini

Toksičnost kemoterapije je čimbenik koji ima najteži učinak na kvalitetu života u bolesnka s karcinomom. Praćenje nuspojava i štetnih učinaka može biti podložno greškama zbog raznih čimbenika kao što je nedostatna zaštita povjerljivosti tijekom prikupljanja podataka, nevoljkosti bolesnika da govori o nekim problemima, neprepoznavanje simptoma i/ili nepoznavanje nuspojava liječenja i/ili neodgovarajući referentni model prikupljanja podataka. Zato smo izradili upitnik za samoprocjenu kako bismo pomogli u ispravnom prikupljanju podataka onima koji pružaju skrb ovim bolesnicima. Upitnik je izrađen uz pomoć provjerenih ljestvica kao što su Common Terminology Criteria for Adverse Event, Edmonton Symptom Assessment Scale i Douleur Neuropathique en 4 Questions. Istraživanje je obuhvatilo bolesnike naručene za kemoterapiju u Dnevnoj bolnici Sveučilišne bolnice Campus Bio-Medico u Rimu u lipnju i srpnju 2015. godine. U tom razdoblju u Dnevnu bolnicu je primljeno 367 bolesnika, 57,5\% žena i 38,4\% muškaraca prosječne dobi od 64 godine, za ukupno 622 pristupa. Od svih tih bolesnika sestrinsko osoblje je samo njih 173 ispitalo o nuspojavama i toksičnosti. Za vrijeme istraživanja bio je uključen 381 bolesnik, od toga 60,1\% žena $(\mathrm{p}=0,8)$ i 38,3\% muškaraca $(\mathrm{p}=0,9)$ prosječne dobi od 63 godine $(\mathrm{p}=0,9)$, za ukupno 611 pristupa i 498 izdanih upitnika za samoprocjenu. Kako bismo procijenili primjenjivost ovoga upitnika, na kraju istraživanja upitnik za njegovu procjenu je podijeljen medicinskom osoblju uključujući pet liječnika i šest medicinskih sestara kako bi razmotrili moguće potrebne dopune ovoga instrumenta te njegovu učinkovitost. Usporedbena analiza podataka prikupljenih tijekom istraživanja pokazala je da je primjena upitnika za samoprocjenu omogućila otkrivanje nuspojava kemoterapije ranije i podrobnije nego kad se to oslanjalo samo na medicinski pregled i nestrukturirani razgovor sestrinskog osoblja s bolesnicima. Uz to, ovom metodom je obuhvaćen veći broj korisnika. U zaključku, primjena sustava za samoprocjenu zajedno sa stručnim radom i kliničkom prosudbom može doprinijeti poboljšanju bolesnikove kvalitete života, pružiti potporu razgovoru sestrinskog osoblja s bolesnikom kroz proces preciznog i sustavnog prikupljanja podataka, čime se znatno smanjuje tumačenje simptoma od strane bolesnika i osoba koje ih njeguju, ali im pruža točne upute o čemu trebaju izvijestiti i kako. Zahvaljujući značajnom i brzom širenju računala, tableta i 'pametnih telefona' može se promišljati o daljnjoj primjeni ovoga sustava kroz njegovu računalnu aplikaciju.

Ključne riječi: Sestrinska njega, postupci; Podaci, prikupljanje; Tumori-farmakoterapija; Antitumorski lijekovi -štetna djelovanja; Ankete i upitnici; Samoprocjena 